Jurnal Psikologi Teori dan Terapan

2014, Vol. 5, No. 1, 52-57, ISSN: 2087-1708

\title{
Konsep Diri dan Kemampuan Pemecahan Masalah Pada Wirausahawan
}

\author{
Anisah Milatus Sunnah, dan Ni Wayan Sukmawati Puspitadewi \\ Program Studi Psikologi Universitas Negeri Surabaya
}

\begin{abstract}
This study aims to know the relationship between self-concept and problem solving ability among entrepreneurs in Surabaya. The design used of the study was a correlational research. The subjects in this study were entrepreneurs of Business Communication Forum (FKB) Ibnu Sina Foundation Surabaya which has 41 number of entrepreneurs. Analytical technique used is Peearson's product moment. The results of this study indicates that self-concept has significant relationship with problem solving ability with positive direction of relationship which can be seen from the level of significant which is 0.000 , so the alternative hypothesis proposed research received. The Rsquare value is 0.549 , which is mean that the 54,9\% of variation in problem-solving ability is influenced by the self-concept and the rest 45,1\% is caused by other factors which is not meassured in this research. The conclusion of this study is that there is a positive relationship between self-concept and problem solving ability.
\end{abstract}

Key words: Problem solving ability, self-concept, entrepreneurs

\begin{abstract}
Abstrak: Penelitian ini bertujuan untuk mengetahui hubungan antara konsep diri dengan kemampuan pemecahan masalah pada wirausahawan di Surabaya. Penelitian ini menggunakan metode kuantitatif korelasional. Penelitian ini menggunakan subjek sebanyak 41 wirausahawan Forum Komunikasi Bisnis (FKB) Yayasan Ibnu Sina Surabaya sebagai sampel penelitian. Teknik analisis data yang digunakan dalam penelitian ini adalah analisis product moment. Hasil penelitian ini menunjukkan bahwa konsep diri memiliki hubungan yang signifikan dengan kemampuan pemecahan masalah dengan arah hubungan yang positif yang dapat dilihat dari nilai signifikasi sebesar 0,000 , maka hipotesis alternatif diterima. Nilai $\mathbf{R}_{\text {square }}$ sebesar 0,549 menunjukkan bahwa sumbangan atau kontribusi yang diberikan variabel konsep diri ialah sebesar 0,549. Artinya, 54,9\% variabel pada kemampuan pemecahan masalah dipengaruhi oleh variabel konsep diri dan sisanya sebesar 45,1\% disebabkan oleh variabel lain yang tidak diukur. Kesimpulan dari penelitian ini adalah terdapat hubungan yang positif antara konsep diri dengan kemampuan pemecahan masalah.
\end{abstract}

Kata Kunci: Kemampuan pemecahan masalah, konsep diri, wirausahawan

Wirausahawan yang bermunculan semakin hari semakin banyak baik itu secara online atau offline. Wirausahawan adalah orang yang mendobrak sistem ekonomi yang ada dengan memperkenalkan barang dan jasa yang baru, dengan menciptakan bentuk organisasi baru atau mengelolah bahan baku baru (Schumpeter, dalam Alma, 2011: 24).

Wirausahawan yang baru bermunculan ini, banyak yang hanya melihat dari sisi keuntungannya saja. Menurut Alma

Korespondensi tentang artikel ini dapat ditujukan kepada Anisah Milatus Sunnah melalui email: anisah.millah@gmail.com 
(2011: 1), keuntungan dari wirausaha itu sendiri antara lain yaitu dapat menentukan tujuan dengan kehendak sendiri, dapat memanfaatkan keuntungan secara maksimal, dapat membantu masyarakat dengan usaha-usaha yang konkrit, serta tidak dipungkiri mendapat kesempatan untuk menjadi bos.

Setiap hal itu pasti ada resiko atau kerugian yang siap menghadangnya yang perlu kita ketahui. Resiko atau kerugian merupakan masalah yang harus dihadapi jika seseorang menginginkan usahanya berjalan terus menerus dan sukses. Resiko tersebut seperti waktu yang digunakan untuk bekerja lebih panjang dan lebih bekerja keras, untuk kualitas hidupnya juga masih rendah sampai usahanya berhasil, serta tanggung jawab yang dipikul juga semakin besar, dan harus memutuskan suatu keputusan meskipun dia belum menguasai permasalahannya (Alma, 2011: 2).

Menurut Sugiyono (2009: 52) masalah adalah penyimpangan antara yang seharusnya dengan apa yang benar-benar terjadi antara teori dengan praktek, antara aturan dengan pelaksanaan, dan antara rencana dengan pelaksanaan. Kesuksesan wirausahawan sangat ditentukan oleh keahliannya dalam menyelesaikan masalah. Masalah yang dihadapi tersebut akan berbeda-beda pada setiap wirausahawan seperti tidak kompeten dalam manajerial, kurang dapat mengendalikan keuangan, lokasi yang kurang memadai, sikap yang kurang sungguh-sungguh dalam berusaha, dan ketidak mampuan dalam melakukan peralihan wirausaha (Zimmerer, dalam Suryana, 2009: 44).

Pemecahan masalah adalah suatu pemikiran yang terarah secara langsung untuk menemukan solusi atau jalan keluar untuk masalah yang spesifik (Solso dkk, 2008: 434). Para wirausahawan hendaknya dapat menganalisis dengan mengumpulkan data-data, mengolahnya, dan menarik kesimpulan dari penganalisisan tersebut. Keterampilan yang diperoleh para wirausa- hawan akan menjadi bekal di dalam pemecahan masalah wirausahanya. Oleh sebab itu, sangat penting diperlukan oleh seorang wirausaha memiliki kemampuan pemecahan masalah yang baik.

Kemampuan pemecahan masalah adalah kemampuan untuk mengenali dan merumuskan masalah serta menemukan cara atau jalan keluar dan menerapkan untuk mengubah kondisi sekarang menjadi kondisi yang diinginkan. Pemecahkan masalah bersifat multi fase dan mensyaratkan kemampuan menjalani proses yaitu memahami masalah dan percaya pada diri sendiri, serta termotivasi untuk memecahkan masalah itu secara efektif, menentukan dan merumuskan masalah sejelas mungkin, menemukan sebanyak mungkin alternatif pemecahan, mengambil keputusan untuk menerapkan salah satu alternatif pemecahan dan kelemahannya.

Kemampuan pemecahan masalah dapat dipengaruhi oleh dua faktor yaitu faktor situasional dan faktor personal (Rakhmat (2003: 73). Faktor situasional terdiri dari stimulus yang menimbulkan masalah dan sifat-sifat masalah. Faktor personal diantaranya yaitu kepercayaan dan sikap yang salah serta kebiasaan.

Kepercayaan dan sikap yang salah jika dimiliki oleh seorang wirausaha maka individu tersebut akan tersesat dalam memecahkan masalah yang dihadapinya dikarenakan kurang percaya diri, menolak informasi baru, keliru dalam merasionalkan sesuatu dan mempersukar penyelesaian masalah. Kebiasaan ini cenderung akan memepertahankan pola pikir tertentu atau keras kepala, hanya melihat satu masalah dari satu sisi saja, memiliki kepercayaan yang berlebihan dan tidak kritis pada pendapat otoritas. Hal tersebut dapat menghambat seseorang untuk menyelesaikan masalahnya secara efisien. Kedua hal tersebut juga merupakan hal yang dimiliki oleh seseorang yang memiliki konsep diri yang negatif.

Rogers (dalam Burns, 1993: 50) mengatakan bahwa konsep diri dapat 
dipandang sebagai suatu sikap yang memiliki dimensi evaluatif dan memiliki kecenderungan mempengaruhi tingkah laku. Tingkah laku tidak hanya dipengaruhi oleh pengalaman-pengalaman masa lalu dan saat ini tetapi oleh makna-makna pribadi masing-masing individu yang diletakkan pada persepsi mengenai pengalaman tersebut (dalam Burns, 1993: $38)$.

Menurut Calhoun dan Acocella (1995: 72) konsep diri positif lebih kepada penerimaan diri bukan sebagai suatu kebanggaan yang besar tentang diri. Individu yang memiliki konsep diri positif adalah individu yang tahu betul tentang dirinya, dapat memahami dan menerima sejumlah fakta yang sangat bermacammacam tentang dirinya, evaluasi terhadap dirinya sendiri menjadi positif dan dapat menerima keberadaan orang lain. Individu yang memiliki konsep diri positif akan merancang tujuan-tujuan yang sesuai dengan realitas, yaitu tujuan yang memiliki kemungkinan besar untuk dicapai dan mampu menghadapi kehidupan di depannya. Individu yang memiliki konsep diri positif, ketika dihadapkan dengan masalah individu akan dapat memecahkan masalahnya dengan merubah tujuan-tujuan yang awalnya sudah direncanakan dengan keadaan saat ini.

Hal yang sama juga dikemukakan oleh Brook dan Emmert (dalam Rakhmat, 2003: 105) individu yang memiliki konsep diri yang positif maka individu tersebut akan memiliki keyakinan akan kemampuannya mengatasi masalah, merasa setara dengan orang lain, menerima pujian tanpa rasa malu, menyadari bahwa setiap orang mempunyai berbagai perasaan, keinginan dan perilaku yang tidak seluruhnya disetujui masyarakat, dan mampu memperbaiki diri karena ia sanggup mengungkapkan aspek-aspek kepribadian yang tidak disenanginya dan berusaha mengubahnya.
Sementara individu yang memiliki konsep diri negatif menutut Brook dan Emmer (dalam Rakhmat, 2003: 105) akan memiliki hal berikut yaitu peka terhadap kritik, responsif terhadap pujian, hiperkritis terhadap orang, individu selalu mengeluh, cenderung merasa tidak disenangi orang lain, keras kepala, akan menganggap dirinya sebagai korban dari sistem sosial yang tidak beres, pesimis terhadap kompetisi dengan ketidakberdayaan menghadapi persaingan yang dihadapi, sehingga berdampak pada kurangnya kemampuan untuk menghadapi dan mengatasi permasalahan.

Penelitian ini bertujuan untuk menguji apakah ada hubungan antara konsep diri dengan kemampuan pemecahan masalah pada wirausahawan.

\section{Metode}

Penelitian ini menggunakan pendekatan kuantitatif korelasional yaitu penelitian yang bertujuan untuk meneliti sejauh mana variabel satu berkaitan dengan variabel lain berdasarkan koefisien korelasi (Azwar, 2008). Penelitian ini dilaksanakan di Forum Komunikasi Bisnis (FKB) Yayasan Ibnu Sina Surabaya. Subjek penelitian ini adalah 41 wirausahawan yang bergabung dalam Forum tersebut.

\section{Teknik pengumpulan data}

Teknik pengumpulan data penelitian ini menggunakan angket. Angket yang digunakan yaitu angket konsep diri disusun berdasarkan dimensi-dimensi konsep diri yaitu pengetahuan tentang diri sebanyak 13 aitem, pengharapan tentang diri sebanyak 11 aitem dan penilaian tentang diri sebanyak 17 aitem. Angket kedua adalah skala kemampuan pemecahan masalah yang disusun berdasarkan aspek sikap terhadap pemecahan masalah sebanyak 15 aitem dan tindakan terhadap pemecahan masalah sebanyak 17 aitem. 


\section{Teknik analisis data}

Teknik analisis data yang digunakan dalam penelitian ini adalah analisis product moment dari Pearson dan analisis regresi. Analisis product moment menggunakan uji asumsi normalitas dan linearitas.

\section{Hasil dan Pembahasan}

Hasil penelitian mengenai hubungan antara konsep diri dengan kemampuan pemecahan masalah pada wirausahawan di Surabaya dapat dilihat dalam tabel analisis Product moment dan analisis regresi berikut ini:

Tabel 1. Hasil analisis product moment

\begin{tabular}{llcc}
\hline & & Kemampuan pemecahan masalah & Konsep diri \\
\hline $\begin{array}{l}\text { Kemampuan } \\
\text { pemecahan }\end{array}$ & Pearson Correlation & 1 & $.741^{* *}$ \\
masalah & Sig. (2-tailed) & & .000 \\
& $\mathrm{~N}$ & 41 & 41 \\
\hline Konsep diri & Pearson Correlation & $.741^{* *}$ & 1 \\
& Sig. (2-tailed) & .000 & \\
& $\mathrm{~N}$ & 41 & 41 \\
\hline
\end{tabular}

Tabel 2. Hasil analisis analisis regresi

\begin{tabular}{lcrr}
\hline \multicolumn{1}{c}{ Hubungan antar variabel } & R & R Square & Adjusted R Square \\
\hline $\begin{array}{l}\text { Konsep diri dengan kemampuan } \\
\text { pemecahan masalah }\end{array}$ & $.741^{\text {a }}$ & .549 & .537 \\
\hline
\end{tabular}

Hasil yang didapatkan dalam uji analisis yang telah dilakukan dengan menggunakan korelasi product moment dari Pearson, menunjukkan bahwa antara konsep diri dengan kemampuan pemecahan masalah memiliki koefisien korelasi sebesar 0,741. Hasil uji analisis tersebut menunjukkan bahwa konsep diri dengan kemampuan pemecahan masalah memiliki hubungan yang kuat sebesar 0,741 .

Nilai koefisien determinasi $\left(\mathrm{R}_{\text {Square }}\right)$ variabel konsep diri dengan kemampuan pemecahan masalah adalah sebesar 0,549. Hal ini berarti kontribusi variabel konsep diri dengan kemampuan pemecahan masalah adalah sebesar 54,9\%. Sedangkan $45,1 \%$ sisanya merupakan variable diluar penelitian yang ikut mempengaruhi variabel kemampuan pemecahan masalah pada wirausahawan.

Hasil penelitian ini menunjukkan bahwa konsep diri memiliki hubungan yang positif terhadap kemampuan pemecahan masalah. Hal ini didukung oleh
Brook dan Emmert (dalam Rakhmat, 2003: 105) yang menyatakan bahwa konsep diri mampu mempengaruhi kemampuan berfikir seseorang. Orang yang konsep dirinya baik akan selalu optimis, berani mencoba hal-hal baru, berani sukses, berani gagal, percaya diri, antusias, merasa diri berharga, berani menetapkan tujuan hidup, bersikap dan berpikir positif, dan dapat menjadi seorang pemimpin yang handal. Orang yang memiliki konsep diri yang jelek akan mengakibatkan rasa tidak percaya diri, tidak berani mencoba hal-hal baru, tidak berani mencoba hal yang menantang, takut gagal, takut sukses, merasa diri bodoh, rendah diri, merasa diri tidak berharga, merasa tidak layak untuk sukses, pesimis.

Suharnan (2005: 279) pada sisi lain juga menyatakan bahwa kebanyakan aktivitas pemecahan masalah melibatkan proses berfikir. Proses berfikir adalah aktivitas kognitif yang terjadi di dalam pikiran seseorang, proses yang melibatkan beberapa manipulasi pengetahuan di dalam 
sistem kognitif, dan aktivitas berfikir yang diarahkan untuk menghasilkan pemecahan masalah. Oleh sebab itu, seorang wirausahawan harus memiliki konsep diri yang baik untuk mendapatkan memecahan masalah yang baik pula.

Menurut Rakhmat (2003: 73) salah satu faktor yang mempengaruhi kemampuan pemecahan masalah yaitu faktor personal. Faktor personal diantaranya yaitu kepercayaan dan sikap yang salah serta kebiasaan. Individu memiliki kepercayaan dan sikap yang salah ketika menghadapi suatu permasalahan maka individu akan tersesat atau tidak mendapatkan cara untuk keluar dari masalah yang sedang dihadapinya. Hal ini akan menghambat keefektifan dalam memecahkan masalah, yang mana ketika suatu masalah tidak dapat terselesaikan dengan baik maka akan mempengaruhi masalah yang lain dan ketika menganggap kecil suatu masalah bisa saja masalah tersebut semakin hari semakin besar. Kebiasaan ini ketika tidak disadari dan cenderung individu ini mempertahankan pola pikir tertentu atau keras kepala, sedangkan keras kepala merupakan ciri dari konsep diri yang negatif maka akan menghambat individu dalam memecahkan masalahnya.

Hasil data penelitian menunjukkan bahwa rata-rata (mean) tiap aspek pada kuesioner konsep diri memiliki rata-rata (mean) tertinggi yaitu pada aspek penilaian kepada diri sendiri, rata-rata (mean) kedua yaitu pengetahuan, dan rata-rata (mean) terrendah yaitu pengharapan pada diri sendiri. Hal ini menunjukkan bahwa para wirausahawan di Forum Komunikasi Bisnis (FKB) Yayasan Ibnu Sina Surabaya memiliki konsep diri yang diwujudkan dalam bentuk penilaian kepada diri sendiri dan pada pengetahuan mereka tentang diri mereka sendiri lebih tinggi daripada diwujudkan dalam bentuk pengharapan pada diri mereka sendiri.

Rata-rata (mean) tiap aspek pada kuesioner kemampuan pemecahan masalah yang memiliki rata-rata (mean) tertinggi yaitu pada aspek tindakan terhadap pemecahan masalah dan rata-rata (mean) terendah yaitu pada aspek sikap terhadap pemecahan masalah. Hal ini menunjukkan bahwa para wirausahawan di Forum Komunikasi Bisnis (FKB) Yayasan Ibnu Sina Surabaya ketika memiliki masalah, mereka lebih cenderung untuk menyelesaikan masalah dengan cara melakukan tindakan secara langsung yang berhubungan dengan masalah yang dihadapinya dengan sikap yang rendah.

Hasil rata-rata (mean) tiap aspek pada masing-masing kuesioner penelitian yaitu kuesioner konsep diri yang memiliki rata-rata (mean) tertinggi terdapat pada aspek penilaian pada diri sendiri dan pengetahuan tentang diri sendiri, dan ratarata (mean) terendah terdapat pada aspek pengharapan pada diri sendiri, yang mana aspek terendah harus diperhatikan oleh wirausahawan yang bergabung dalam Forum Komunikasi Bisnis (FKB) Yayasan Ibnu Sina Surabaya untuk lebih meningkatkan lagi supaya dapat menjalankan wirausahanya dengan baik dengan mampu mengenali dirinya. Kuesioner kemampuan pemecahan masalah memiliki rata-rata yang tertinggi pada aspek tindakan dan rata-rata terendah yaitu sikap, aspek sikap tersebut harus diperhatikan oleh para wirausahawan yang bergabung dalam Forum Komunikasi Bisnis (FKB) Yayasan Ibnu Sina Surabaya agar dapat memecahkan masalah yang dihadapi dengan kemampuan pemecahan masalah yang dimiliki masing-masing wirausahawan. Karena tidak hanya tindakan saja yang diperlukan dalam memecahkan masalah, namun sikap juga diperlukan sebelum melakukan tindakan dalam pemecahan masalah.

Nilai koefisien determinasi $\left(\mathrm{R}^{2}\right)$ variabel konsep diri dengan kemampuan pemecahan masalah menunjukkan bahwa terdapat variabel-variabel atau variasi diluar penelitian yang ikut mempengaruhi kemampuan pemecahan masalah pada 
wirausahawan. Hal ini sesuai dengan Khaerunnisa (2013: 2) yang menyatakan bahwa aspek psikologis turut memberikan kontribusi terhadap kesuksesan seseorang yang memiliki kemampuan dalam menghadapi dan menyelesaikan masalah dengan baik selain aspek kognitif. Salah satu aspek psikologis tersebut yaitu konsep diri. Variabel atau variasi atau faktor lain yang dapat mempengaruhi di luar penelitian ini bisa seperti kecerdasan emosi, intelegensi, efikasi diri, harga diri, pengetahuan, dukungan sosial, motivasi, dan lainnya.

\section{Simpulan}

Penelitian yang telah dilakukan di Forum Komunikasi Bisnis Yayasan Ibnu Sina Surabaya menunjukkan bahwa konsep diri memiliki nilai koefisien korelasi sebesar 0,741. Hal ini dapat diketahui bahwa antara konsep diri memiliki hubungan yang kuat dan positif atau berjalan searah dengan kemampuan pemecahan masalah. Artinya, ada hubungan yang positif antara konsep diri dengan kemampuan pemecahn masalah. Hal ini berarti apabila semakin tinggi konsep diri wirausahawan maka semakin tinggi pula kemampuan pemecahan masalah yang dimiliki.

\section{Daftar Pustaka}

Alma, Buchari. (2011). Kewirausahaan. Bandung: Alfabeta.

Azwar, S. (2008). Metode Penelitian. Yogyakarta: Pustaka Pelajar.

Burns, R. B. (1993). Konsep Diri (Teori, Pengukuran, Perkembangan dan Perilaku). Diterjemahkan oleh Eddy. Jakarta: Arcan.

Calhoun, J. F. dan Accocella, J. R. (1995). Psikologi Tentang Penyesuaian dan Hubungan Kemanusiaan. Edisi III. Diterjemahkan oleh Satmoko. Semarang: IKIP Semarang Press.

Khaerunnisa, E. (2013). Peningkatan Kemampuan Pemecahan Masalah dan Adversity Quotient Matematis Siswa MTS Melalui Pendekatan
Pembelajaran Eksploratif. Universitas Pendidikan Indonesia.

Rakhmat, J. (2003). Psikologi Komunikasi. Jakarta: PT Remaja Rosda Karya.

Solso, R. T., Maclin, O. T., \& Maclin, M. K. 2008. Psikologi Kognitif. Terjemahan : Rahardanto \& Batuadji. Jakarta: Erlangga.

Suharnan. (2005). Psikologi Kognitif. Surabaya: Srikandi.

Sugiyono. (2009). Metode Penelitian Pendidikan. Bandung: Alfabeta.

Suryana. (2009). Kewirausahaan Pedoman Praktis: Kiat dan Proses Menuju Sukses Edisi III. Jakarta: Salemba Empat. 